\title{
Recombination and UV resistance of Escherichia coli with the cloned recA and recBCD genes of Serratia marcescens and Proteus mirabilis: evidence for an advantage of intraspecies combination of $P$. mirabilis RecA protein and RecBCD enzyme
}

\author{
JOHANN DE VRIES and WILFRIED WACKERNAGEL* \\ Fachbereich Biologie, Genetik, Universität Oldenburg, D-2900 Oldenburg, Germany
}

(Received 24 May 1991; revised 15 October 1991; accepted 21 October 1991)

\begin{abstract}
In Escherichia coli, constituents of the main recombination pathway are provided by the genes rec $A$ (RecA protein) and recBCD (RecBCD enzyme). Recombination in conjugation experiments and repair of UV damage of $E$. coli mutants deleted for $\operatorname{rec} A$, for $\operatorname{rec} B C D$ or for $\operatorname{rec} A$ plus rec $B C D$ were restored, although to different degrees, by the cloned rec $A$ and recBCD genes from Serratia marcescens or Proteus mirabilis. When both recombination enzymes were from the same species, repair and recombination efficiencies had the order $E$. coli $>S$. marcescens $>P$. mirabilis. However, the $P$. mirabilis rec $A$ plus rec $B C D$ genes resulted in higher levels of repair and recombination than those obtained with one component from $P$. mirabilis (recA or $\operatorname{recBCD}$ ) and the other from $E$. coli or $S$. marcescens. The data provide evidence for the similarity of RecABCD pathways of recombination among enteric bacteria and suggest an in vivo advantage of an intraspecies combination of $P$. mirabilis RecA protein and RecBCD enzyme over interspecies combinations. This could point to a cooperation between these basic recombination enzymes. The molecular processes which could be involved are discussed.
\end{abstract}

\section{Introduction}

The major recombination pathway in Escherichia coli following DNA transfer by conjugation or transduction is the RecBCD pathway (Clark, 1973). Genetic studies have revealed the dependence of this pathway on RecA protein and RecBCD enzyme, but also on other activities of DNA metabolism including DNA gyrase, DNA ligase, single-stranded DNA binding protein (SSB) and DNA polymerase I (for reviews, see Mahajan, 1988; Smith, 1988). Mutations in $\operatorname{rec} A$ reduce recombination proficiency by about four orders of magnitude, mutations in $\operatorname{rec} B$ or $\operatorname{rec} C$ by about two (Willetts \& Clark, 1969). In vitro RecA protein catalyses several reactions including homologous alignment of single- or doublestranded DNA with another homologous doublestranded DNA molecule and the ATP-dependent singlestrand transfer between these substrates (for reviews, see Cox \& Lehman, 1987; Radding, 1988). In addition, RecA protein accelerates renaturation of complementary single strands. RecBCD enzyme, also termed exonuclease $V$, was found to have ATP-dependent single-

\footnotetext{
* Author for correspondence. Tel. 0441798 3298; fax 04417983250.
}

and double-strand exonuclease and single-strand endonuclease activities (for a review, see Telander-Muskavitch \& Linn, 1981). Moreover, the RecBCD enzyme is an ATP-dependent helicase that during unwinding of DNA recognizes and cleaves specific octanucleotide sequences called Chi (Ponticelli et al., 1985; Schultz \& Smith, 1986). The latter two activities have been correlated to the enzyme's function in recombination (see Smith, 1988). Chi sites have been shown to enhance RecBCD-dependent recombination in their vicinity (Smith \& Stahl, 1985). As has been confirmed by in vitro experiments (Roman \& Kowalczykowski, 1989 b; Wang $\&$ Smith, 1989), RecA protein can use the single-stranded DNA produced by RecBCD enzyme helicase activity to promote the strand transfer reaction.

In the well-established genetic system of $E$. coli homologous recombination can be measured by parasexual processes such as conjugation and transduction or by phage crosses. In most other bacterial species similar processes have not been elaborated or even been detected so far. Therefore, a measurement of recombination proficiency in these organisms is impossible.

Although the existence of RecA proteins and of RecBCD enzymes in various bacterial species (Telander- 
Muskavitch \& Linn, 1981; Smith, 1988; McKittrick \& Smith, 1989) predicts a broad distribution of the RecBCD pathway of recombination among prokaryotes, the existence of such pathways in bacteria other than $E$. coli has not yet been shown. We have investigated recombination by RecA plus RecBCD enzymes of the two enterobacteria Serratia marcescens and Proteus mirabilis. To circumvent the problem of not having a means to measure recombination in these species at present, we transformed the cloned $\operatorname{rec} A$ and $\operatorname{rec} B C D$ genes of $S$. marcescens and $P$. mirabilis into $E$. coli deleted for these genes. In the transformants we determined recombination proficiency provided by the heterologous enzymes using the conjugation system of $E$. coli. In addition, the UV sensitivity of the transformants was used as a measure of their DNA repair potential dependent on recombination functions.

The experimental approach of reconstituting the recombination system of one species in the cells of another species allows us to study a new aspect. This is whether the enzymes performing the different steps of recombination work with the same efficiency if they come from different species as if they come from the same species. The data obtained provide evidence for a cooperation of RecA protein with RecBCD enzyme in the sense that with both enzymes from the same species (P. mirabilis) higher efficiencies of repair and recombination were obtained than with interspecies combinations including only one $P$. mirabilis enzyme.

\section{Methods}

Bacterial strains and plasmids. Table 1 contains the description of bacterial strains and plasmids used in this study. Strains were constructed by $\mathrm{Pl}$ transduction (Miller, 1972). In the main studies mutants deleted for $\operatorname{rec} A$ and/or $\operatorname{rec} B C D$ (strains JV1, JV3, JV10 and JV12) were used. They were derived from strain WA675 (Weichenhan \& Wackernagel, 1988) and therefore are isogenic, apart from the noted genotype differences (Table 1).

DNA manipulations. Plasmid DNA was isolated by alkaline lysis (Birnboim \& Doly, 1979). Restriction enzymes were purchased from Boehringer Mannheim, Pharmacia and Gibco/BRL and were used as recommended by the supplier. T4 DNA ligase was isolated as described by Murray et al. (1979). Ligations were performed according to Rusche \& Howard-Flanders (1985). Standard molecular cloning procedures were used (Maniatis et al. 1982).

Media and growth conditions. Strains were grown in TBY broth $\left(1^{-1}\right.$ : $10 \mathrm{~g}$ tryptone, $5 \mathrm{~g}$ yeast extract, $5 \mathrm{~g} \mathrm{NaCl}$ ) at $37^{\circ} \mathrm{C}$. If needed, thymine was added to a final concentration of $50 \mu \mathrm{g} \mathrm{m}^{-1}$. For strains carrying plasmids, the appropriate antibiotics were added to give the following final concentrations: ampicillin (Ap), $40 \mu \mathrm{g} \mathrm{m}^{-1}$; chloramphenicol (Cm), $20 \mu \mathrm{g} \mathrm{ml}^{-1}$; kanamycin ( $\left.\mathrm{Km}\right), 15 \mu \mathrm{g} \mathrm{ml}^{-1}$; tetracycline (Tc), $7 \mu \mathrm{g} \mathrm{ml}^{-1}$. Agar plates containing mitomycin $\mathrm{C}$ at a concentration of $1 \mu \mathrm{g} \mathrm{ml}^{-1}$ were used for rapid discrimination between $\operatorname{rec} A$ and $\operatorname{rec} A^{+}$ as well as between $\operatorname{rec} B C D$ and $\operatorname{rec} B C D^{+}$cells by replica plating of colonies from transformation plates.
Exponential-phase cultures for conjugation experiments or for determination of UV sensitivity were grown without antibiotics. Since we observed that the formation of exconjugant colonies by antibioticresistant cells was somewhat hampered on plates containing antibiotics, the plates for determination of recombinants and exconjugants, or for determination of survivors were prepared without the antibiotics selecting for the presence of $\operatorname{rec} A$ or $\operatorname{rec} B C D$ plasmids. Under these conditions we found that two plasmids (pDV31 and pPG35) were lost in up to $50 \%$ of the exconjugants or UV survivors. Therefore, the actual fraction of plasmid-carrying, recombination-proficient cells was determined in each experiment by replica-plating the colonies appearing on plates with non-irradiated cells (UV experiment) or with exconjugants onto media selective for the presence of pDV31 or pPG35. The colony titres of UV survivors and exconjugants were corrected accordingly.

Determination of UV resistance and recombination proficiency. Determination of UV resistance was performed as described by Thoms \& Wackernagel (1982). Bacterial matings were performed using the $\mathrm{HfrH}$ strain JC158(pML.2) (Lovett \& Clark, 1983) as donor, which allows the determination of recombination and conjugation frequency in the same cross. The transfer origin is located at $98 \mathrm{~min}$ on the $E$. coli chromosome and DNA is transferred in a clockwise direction towards pro $A^{+}(6 \mathrm{~min})$. Conjugation proficiency was determined by the recombinationindependent transfer of the mobilizable plasmid pML2, which confers kanamycin resistance to the recipients. For a given recipient strain, the transfer of pML2 was not measurably affected by the presence of one of the plasmids carrying the various rec genes. Matings were performed at $37^{\circ} \mathrm{C}$ in TBY with a ratio of recipient to $\mathrm{Hfr}$ cells of 10 . They were interrupted by vigorous vortexing after $40 \mathrm{~min}$ to block transfer of $\mathrm{rec}^{+}(59 \mathrm{~min})$ and $\mathrm{rec} B^{+} C^{+} D^{+}$genes $(61 \mathrm{~min})$ to the recipient cells (map positions according to Bachmann, 1990). Counterselection against the Hfr strain was done by not providing serine and thiamin in the M9 minimal medium plates for which the Hfr strain is auxotrophic. In each cross 100-200 recombinant colonies (on M9 with thymine and arginine) and exconjugant colonies (on M9 with thymine, arginine, proline and kanamycin) were scored. The recombination frequency of a given strain was calculated by dividing the titre of $\mathrm{pro}^{+}$recombinants by the titre of $\mathrm{Km}^{R}$ exconjugants for each recipient strain tested and normalized to the value obtained with $E$. coli $\operatorname{rec} A^{+} \operatorname{rec} B^{+} C^{+} D^{+}$. The standard deviation for these recombination frequencies was calculated from three or more independent experiments.

\section{Results}

\section{Cloning of the recA genes of Serratia marcescens and Proteus mirabilis}

A genomic library was constructed from Sau3AIdigested chromosomal DNA of $S$. marcescens SR41 (Takagi \& Kisumi, 1985) by ligation of $23-35 \mathrm{~kb}$ fragments into the BamHI site of the mini-F-derived single-copy cosmid pRE432 (Table 1, Fig. 1). To screen for the recA gene of $S$. marcescens $\left(\right.$ rec $\left._{S m}\right)$ E. coli recAl (strain DH5, Table 1) was transformed with these cosmids and replica-plated onto TBY plates with mitomycin $\mathrm{C}\left(1 \mu \mathrm{g} \mathrm{ml}^{-1}\right)$. From one cosmid, which restored mitomycin resistance, $\operatorname{rec} A_{S m}$ was recloned on a $1.7 \mathrm{~kb}$ EcoRI fragment into pRE432. The gene was identified by the restoration of UV resistance and 
Table 1. Bacterial strains and plasmids

\begin{tabular}{|c|c|c|}
\hline Strain or plasmid & Description & Construction, source or reference \\
\hline Proteus mirabilis PG1300 & arg thr end $1-199$ & Eitner et al. (1981) \\
\hline Serratia marcescens $\mathrm{Sr} 41$ & Wild-type & Takagi \& Kisumi (1985) \\
\hline $\begin{array}{l}\text { Escherichia coli strains: } \\
\text { K12s } \\
\text { DH5 } \\
\text { JC10289 } \\
\text { WA675 } \\
\text { JV1 } \\
\text { JV10 } \\
\text { JV3 } \\
\text { JV12 } \\
\text { JC158 (pML2) }\end{array}$ & 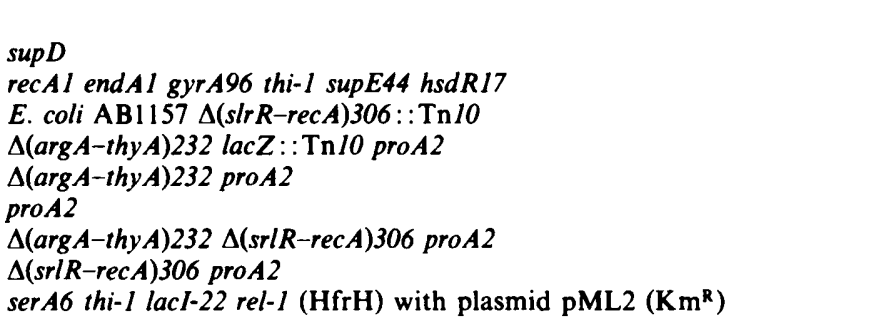 & $\begin{array}{l}\text { Bachmann }(1972) \\
\text { Hanahan (1983) } \\
\text { Csonka \& Clark (1979) } \\
\text { Weichenhan \& Wackernagel (1988) } \\
\text { K-12s } \rightarrow \text { WA675* } \\
\text { K-12s } \rightarrow \text { JV1* } \\
\text { JC10289 } \rightarrow \text { JV1*† } \\
\text { JC10289 } \rightarrow \text { JV10*† } \\
\text { Lovett \& Clark }(1983)\end{array}$ \\
\hline Plasmids: & & \\
\hline $\begin{array}{l}\text { pRE432 } \\
\text { pJE256 } \\
\text { pNE1 } \\
\text { pPG35 } \\
\text { pSG1 }\end{array}$ & $\begin{array}{l}\mathrm{Ap}^{\mathrm{R}} \mathrm{Cm}^{\mathrm{R}} \mathrm{Tc}^{\mathrm{R}}, 13.5 \mathrm{~kb} \text { (mini-F origin) } \\
\mathrm{Cm}^{\mathrm{R}} \mathrm{Tc}^{\mathrm{R}}, 6 \cdot 5 \mathrm{~kb}(\mathrm{mini}-\mathrm{F} \text { origin) } \\
\left(\arg A^{+} \text {recBCD } D^{+} \text {thy } A^{+}\right) \text {of } S \text {. marcescens in vector } \mathrm{pRE} 432, \mathrm{Ap}^{\mathrm{R}} \mathrm{Cm}^{\mathrm{R}} \\
\left(\text { rec } B C D^{+} \text {thy } A^{+}\right) \text {of } P \text {. mirabilis in vector } \mathrm{pJRD} 84, \mathrm{Ap}^{\mathrm{R}} \mathrm{Tc}^{\mathrm{R}} \\
\text { Cosmid from genomic library of } S \text {. marcescens } \mathrm{Sr} 41, \operatorname{rec} A^{+}, \mathrm{Ap}^{\mathrm{R}} \mathrm{Cm}^{\mathrm{R}} \\
\text { (vector } \mathrm{pRE} 432 \text { ) }\end{array}$ & $\begin{array}{l}\text { R. Eichenlaub University Bielefeld, FRG } \\
\text { R. Eichenlaub University Bielefeld, FRG } \\
\text { Rinken et al. (1991) } \\
\text { Weichenhan \& Wackernagel (1988) } \\
\text { This work }\end{array}$ \\
\hline $\begin{array}{l}\text { pDV1 } \\
\text { pDV11 } \\
\text { pPM12 }\end{array}$ & $\begin{array}{l}\text { rec } A^{+} \text {of } S \text {. marcescens in vector } \mathrm{pRE} 432, \mathrm{Ap}^{\mathrm{R}} \mathrm{Cm}^{\mathrm{R}} \\
\text { rec } A^{+} \text {of } S \text {. marcescens in vector } \mathrm{pRE} 432, \mathrm{Ap}^{\mathrm{R}} \mathrm{Tc}^{\mathrm{R}} \\
\text { Plasmid from genomic library of } P \text {. mirabilis } \mathrm{PG} 1300, \operatorname{rec} A^{+}, \mathrm{Ap}^{\mathrm{R}} \\
\text { (vector pBR322) }\end{array}$ & $\begin{array}{l}\text { This work } \\
\text { This work } \\
\text { This work }\end{array}$ \\
\hline $\begin{array}{l}\text { pDV31 } \\
\text { pSS1 } \\
\text { pPS2 }\end{array}$ & $\begin{array}{l}\text { rec } A^{+} \text {of } P \text {. mirabilis in vector pJE256, } \mathrm{Cm}^{\mathrm{R}} \\
\text { Cointegrate of } \mathrm{pDV} 11 \text { and } \mathrm{pNE} 1, \mathrm{Ap}^{\mathrm{R}} \mathrm{Cm}^{\mathrm{R}} \mathrm{Tc}^{\mathrm{R}} \\
\text { Cointegrate of } \mathrm{pDV} 31 \text { and } \mathrm{pNE} 1, \mathrm{Ap}^{\mathrm{R}} \mathrm{Cm}^{\mathrm{R}}\end{array}$ & $\begin{array}{l}\text { This work } \\
\text { This work } \\
\text { This work }\end{array}$ \\
\hline
\end{tabular}

- The donor and recipient strain used for strain construction by P1 transduction are indicated.

† Spontaneous Tc-sensitive mutants of the originally Tc-resistant transductants, which have probably lost $\mathrm{Tn} 10$, were isolated by the procedure of Maloy \& Nunn (1981) with minor modifications.

recombination proficiency of an $E$. coli $\operatorname{rec} A$ deletion mutant (see following sections) and by hybridization with a probe made from a $0.7 \mathrm{~kb} E c o \mathrm{RI}-N c o I$ fragment of the E. coli recA gene (Sancar et al., 1980) (data not shown). While this work was in progress, cloning of the rec $A$ genes of two other $S$. marcescens strains was published. In strain SM6 the gene was also found on a $1.7 \mathrm{~kb}$ EcoRI fragment (Ball et al., 1990), while no EcoRI restriction sites were found near to the $r e c A$ gene of strain SM250 (Liao \& Liu, 1989), indicating heterogeneity between the strains at least in intergenic regions.

Cloning of the $\operatorname{rec} A$ gene of $P$. mirabilis $\left(\operatorname{rec} A_{P m}\right)$ became necessary because the existing clones were lost after the sequencing of the gene (Akaboshi et al., 1989) was completed (Stephen West, personal communication). A genomic library of $P$. mirabilis PG1 300 (Eitner et al., 1981) was constructed with chromosomal DNA fragmented with Sau3AI to a size of $10-15 \mathrm{~kb}$ and cloned into the BamHI site of pBR322 (Bolivar et al. 1977). Screening of clones on mitomycin $\mathrm{C}$ medium (see previous paragraph) identified one plasmid from which, after a partial Sau3AI digest, a $4.2 \mathrm{~kb}$ fragment covering $\operatorname{rec} A$ was cloned into the BamHI site of the mini-Fderived single-copy vector pJE256 (Table 1, Fig. 1a). As for the rec $A$ gene of $S$. marcescens (previous paragraph), the presence of $\operatorname{rec} A_{P m}$ on this plasmid was confirmed by the restoration of $U V$ resistance and recombination proficiency of a rec $A$ deletion mutant of $E$. coli (see following sections) and by hybridization with the $E$. $\operatorname{coli} r e c A$ gene probe (data not shown). Furthermore, restriction mapping (Fig. 1a) was consistent with the previously published map (Eitner et al., 1981) and with the data obtained by sequencing (Akaboshi et al. 1989).

\section{$U V$ resistance conferred upon $E$. coli by heterologous rec $A$ and rec $B C D$ genes}

The plasmids with $\operatorname{rec} A_{S m}$ (pDV11) or $\operatorname{rec} A_{P m}$ (pDV31) increased the UV resistance of an $E$. coli recAl mutant (strain DH5) only to an intermediate level. At $60 \mathrm{~J} \mathrm{~m}^{-2}$ the survival of $E$. coli wild-type was about $15 \%$, whereas that of pDV11 or pDV31 transformants of DH5 was about $1 \%$ (survival of DH5 without plasmid: $<10^{-5}$ ). It has been shown that the rec $A l$ allele is dominant over the wild-type allele, resulting in negative complementation (Yancey \& Porter, 1984). Accordingly, when the recA gene was deleted from $E$. coli (strain JV12), the foreign $r e c A$ genes restored the repair capacity to much higher 
(a)
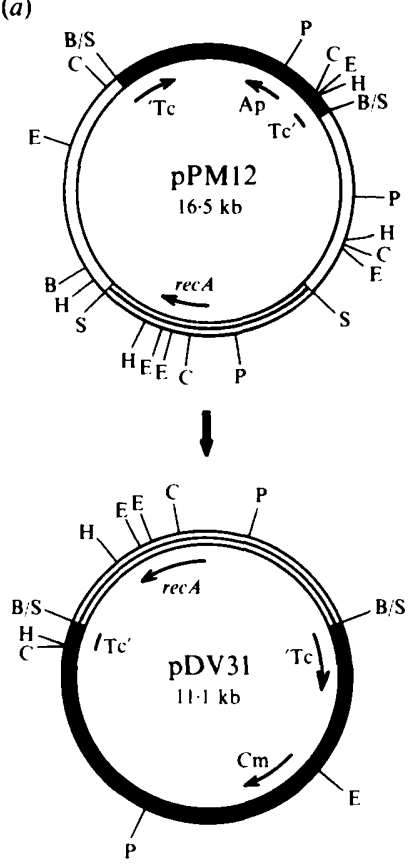

(b)
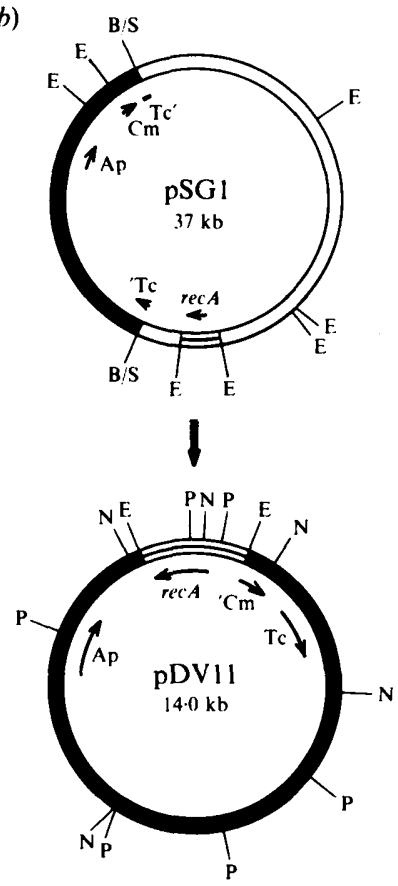

Fig. 1. Construction of single-copy plasmids carrying the rec $A$ genes of $P$. mirabilis $(a)$ and $S$. marcescens $(b)$ from plasmids of genomic libraries (top row). The vectors (represented by filled sections) are pBR322 in pPM12, pJE256 (single-copy) in pDV31 and pRE432 (single-copy) in pSG1 and pDV11. The open sections represent insert DNA; the subcloned parts are emphasized by a third line. The transcription direction of $r e c A_{P m}$ was deduced from $E c o$ RI and $C l a I$ restriction sites according to Akaboshi et al. (1989), that of $r e c A_{S m}$ was deduced from EcoRI, Ncol and PstI restriction sites according to Ball et al. (1990). Abbreviations: B, BamHI; C, ClaI; E, EcoRI; H, HindIII; K, KpnI; N, NcoI; P, PstI; S, Sau3AI (only relevant sites indicated); B/S, BamHISau3AI ligation site; Ap, $\mathrm{Cm}, \mathrm{Tc}$, ampicillin, chloramphenicol, tetracycline resistance; ' $\mathrm{Tc}, \mathrm{Tc}^{\prime},{ }^{\prime} \mathrm{Cm}$, parts of cleaved gene.

degrees, the rec $A_{S m}$ being slightly more effective than the $\operatorname{rec} A_{P m}$ (Figs $2 a$ and $b$ ). It is concluded that (i) the RecA proteins of $S$. marcescens and $P$. mirabilis are active in $E$. coli and that (ii) both are also negatively complemented by the chromosomal recA $I_{E c}$ (recAl from $E$. coli) as is the cloned wild-type allele of $E$. coli.

In a strain deleted for the $\operatorname{rec} A$ and $\operatorname{rec} B C D$ genes (E. coli JV3) the rec $A$ and $\operatorname{rec} B C D$ genes from the same or from different species were combined by double transformations. Since pNE1 and pDV11 or pDV31 are not compatible, strains with spontaneous cointegrates of these plasmids were isolated on plates containing antibiotics selecting for both plasmids. The cointegrated plasmids were named pSS1 $\left(\operatorname{rec} A_{S m} \operatorname{rec} B C D_{S m}\right)$ and pPS2 $\left(\right.$ rec $\left.A_{P m} \quad r e c B C D_{S_{m}}\right)$ (Table 1) and were shown by restriction analysis to contain the complete cloned fragments with the $\operatorname{rec} A$ and $\operatorname{rec} B C D$ genes, respectively (data not shown). The restoration of $\mathrm{UV}$ resistance
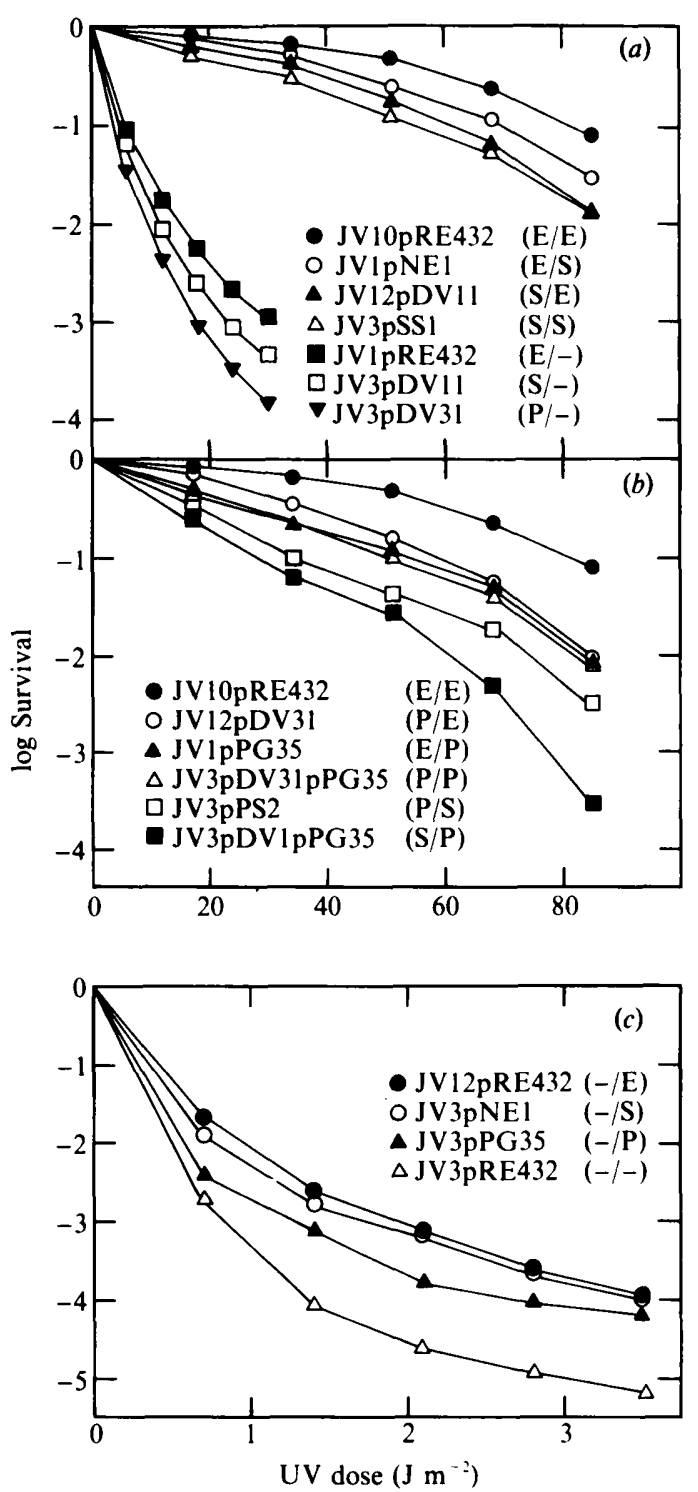

Fig. 2. UV resistance of $E$. coli strains with combined heterologous $\operatorname{rec} A$ and $\operatorname{rec} B C D$ genes. The two letters in parentheses indicate the origin of rec $A / \operatorname{rec} B C D$ genes present in the strains $(E, E$. coli; $\mathrm{S}, S$. marcescens; $\mathrm{P}, P$. mirabilis). A dash indicates the absence of genes. (a) Strains in which $E$. coli and $S$. marcescens genes are combined, and recBCD deletion strains; $(b)$ strains in which $P$. mirabilis genes are combined with $E$. coli or $S$. marcescens genes; (c) recA deletion strains. The curves are means of two or three experiments.

conferred by the $\operatorname{rec} A$ plus $\operatorname{rec} B C D$ genes coming from the same species decreased in the order $E$. coli $>S$. marcescens $>P$. mirabilis (Figs $2 a$ and $b$ ). Remarkably, restoration by the two $P$. mirabilis enzymes [JV3(pDV31)(pPG35)] was higher than when the two components came from different species, such as $\operatorname{rec} A_{P m} \operatorname{recBCD} D_{S_{m}}[\mathrm{JV} 3(\mathrm{pPS} 2)]$ or $\operatorname{rec} A_{S m} \operatorname{rec} B C D_{P_{m}}$ [JV3(pDV1)(pPG35)] (Fig. 2b). A similar advantage of 


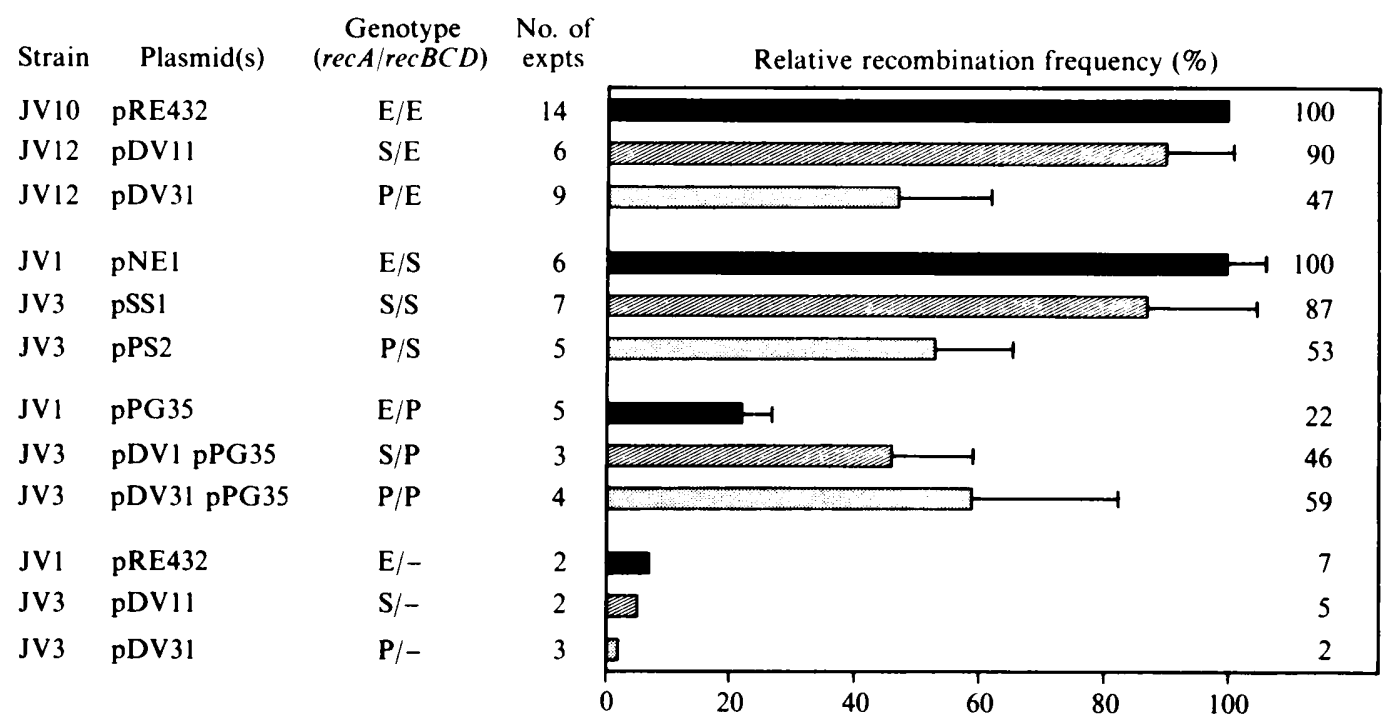

Fig. 3. Recombination proficiency of $E$. coli strains with rec $A$ and $r e c B C D$ genes from $E$. coli, $S$. marcescens and $P$. mirabilis. The recombination frequencies in Hfr crosses using the strains listed above as recipients were performed and evaluated as described in Methods. The origin of the rec $A$ and $r e c B C D$ genes is indicated by capital letters (E, E. coli; $\mathrm{S}, S$. marcescens; $\mathrm{P}, P$. mirabilis). A dash indicates the absence of genes. The recombination frequencies in strains without $r e c A$ genes (not included in the figure) were lower than the limit of detection $(0.3 \%)$, irrespective of the presence or absence of recBCD genes.

an intraspecies over several interspecies combinations was also observed in recombination studies (see next section). [In the strain JV3(pDV1)(pPG35) plasmid pDV1 containing $\operatorname{rec} A_{S m}$ was used instead of pDV11 to select double transformants with pPG35, which has identical antibiotic resistance genes to pDV11 (Table 1). Plasmids pDV1 and pDV11 conferred identical UV resistance upon an $E$. coli recAl mutant (data not shown)].

In those strains missing either $\operatorname{rec} A$ or $\operatorname{rec} B C D$ genes, the UV resistance decreased depending on the origin of the residual recombination enzyme again in the order $E$. coli $>S$. marcescens $>P$. mirabilis (Figs $2 a$ and $c$ ).

\section{Restoration of recombination proficiency by heterologous $\operatorname{rec} A$ and $\operatorname{rec} B C D$ genes}

The relative recombination frequencies determined in 66 conjugation experiments with 12 recipient strains are summarized in Fig. 3. In the $\operatorname{rec} A$ deletion mutant $E$. coli $\mathrm{JV12}$, the activity of $\operatorname{rec} A_{\mathrm{Sm}}$ (located on pDV11) produced $90 \%$ of the $E$. coli wild-type level of recombination, whereas rec $A_{P m}$ (on pDV31) provided only $47 \%$. A similarly decreasing order of recombination frequencies was obtained in strains with the recBCD genes of $S$. marcescens instead of the $E$. coli recBCD genes and with the rec $A$ gene from $E$. coli $(100 \%)$, S. marcescens $(87 \%)$ or P. mirabilis (53\%).
Strains carrying the recBCD genes of $P$. mirabilis showed generally reduced recombination proficiencies compared to the $E$. coli wild-type. The recombination frequencies were highest with the $\operatorname{rec} A$ gene of $P$. mirabilis and lower with recA of $E$. coli or $S$. marcescens. Similar to what was observed in the UV resistance studies, there was a recombinational advantage of the strain with the recA and recBCD genes of $P$. mirabilis over strains carrying interspecies combinations of the genes, i.e. the combination $\operatorname{rec} A_{P m} \operatorname{rec} B C D_{P_{m}}$ was more efficient than the combinations $\operatorname{rec} A_{E c} \operatorname{rec} B C D_{P_{m}}, \operatorname{rec} A_{S m}$ $\operatorname{rec} B C D_{P m}, \operatorname{rec} A_{P m} \operatorname{rec} B C D_{E c}$, and $\operatorname{rec} A_{P m} \operatorname{recBCD} D_{S m}$ (Fig. 3, see Discussion).

Recombination in strains lacking $\operatorname{rec} B C D$ genes was low and followed the same decreasing tendency as reported for UV resistance, i.e. $\operatorname{rec} A_{E c}>\operatorname{rec} A_{S m}>\operatorname{rec} A_{P m}$ (Fig. 3). Recombination in strains without a $\operatorname{rec} A$ gene was below the limit of detection $(0.3 \%)$, irrespective of the presence or absence of $\operatorname{rec} B C D$ genes.

Taken together, there is a high correlation of recombination proficiency and $\mathrm{UV}$ resistance for all 16 strains examined having all possible combinations of the recA and $\operatorname{rec} B C D$ genes from three enteric bacteria. Both phenotypes decreased stepwise upon replacement of $E$. coli rec $A$ plus $\operatorname{rec} B C D$ by the corresponding genes of $S$. marcescens and $P$. mirabilis. Even lower degrees of repair and recomtination were obtained with several interspecies combinations. 


\section{Discussion}

The rec $A$ genes from $S$. marcescens and $P$. mirabilis cloned into single-copy vectors are sufficiently expressed to restore near wild-type levels of recombination proficiency and UV resistance to a $\operatorname{rec} A$ deletion mutant of $E$. coli. Both are partially recessive to the $r e c A l$ allele of $E$. coli. This is concluded from the fact that the UV resistance conferred upon $E$. coli $\Delta r e c A$ significantly exceeded the UV resistance conferred upon $E$. coli rec $A 1$. This is in agreement with previous observations on negative complementation of $\operatorname{RecA}$ protein by the RecAl polypeptide in E. coli (Yancey \& Porter, 1984; Sedgwick \& Goodwin, 1985). It indicates that like wildtype $E$. coli RecA protein, the RecA proteins of $S$. marcescens and $P$. mirabilis form heteropolymers with the recAl mutant polypeptide in vivo.

It has already been reported that the $E$. coli $\operatorname{rec} B C D$ genes can be replaced by gene groups isolated from $P$. mirabilis and $S$. marcescens (Weichenhan \& Wackernagel, 1988; McKittrick \& Smith, 1989; Rinken et al., 1991). In vivo several hybrid enzymes composed from subunits of $E$. coli, $S$. marcescens and $P$. mirabilis formed and exhibited varying levels of recombinational activity, although the restriction maps of the recBCD genes from the three species were quite different (Weichenhan \& Wackernagel, 1988; Rinken et al., 1991).

The rec $A$ and recBCD genes of $S$. marcescens or $P$. mirabilis, when simultaneously replacing the equivalent E. coli genes, promoted conjugational recombination and repair of UV damage. This suggests the existence of pathways of recombination in $S$. marcescens and $P$. mirabilis similar or identical to the RecBCD pathway of $E$. coli. These pathways are expected to recognize Chi sequences as hot spots of recombination because the respective RecBCD enzymes do that in $E$. coli (Weichenhan \& Wackernagel, 1988, 1989; McKittrick \& Smith, 1989). The observed recombination proficiencies conferred by intraspecies pairs of recA plus $\operatorname{rec} B C D$ genes in $E$. coli had the order $E$. coli $>S$. marcescens $>P$. mirabilis (Fig. 3) and resembled the decrease of the repair capacities (Fig. 2).

An important result of this work was the observation that the potential of recombination (and repair) of several interspecies enzyme combinations was even lower than the lowest value obtained with the 'parental' intraspecies combinations. Specifically, the interspecies combinations $\operatorname{rec} A_{E c} \operatorname{rec} B C D_{P_{m}}, \operatorname{rec} A_{S m} \operatorname{rec} B C D_{P_{m}}$, $\operatorname{rec} A_{P m} \operatorname{rec} B C D_{E c}$, and $\operatorname{rec} A_{P_{m}} \operatorname{rec} B C D_{S m}$ all failed to reach the level obtained with the intraspecies combination of the two P. mirabilis enzymes (Fig. 3). The lower efficiencies cannot result from an insufficient expression of the $P$. mirabilis genes or a low activity of the $P$. mirabilis RecA protein or RecBCD enzyme produced in
$E$. coli, because together they achieved a higher level of recombination than any of the interspecies combinations. Also, the genes of $E$. coli and $S$. marcescens were expressed sufficiently, because they, when combined with genes from the same species, produced high levels of recombination. Thus, if not the activity of the single enzyme components, what is the reason for the hampered recombination in interspecies systems? We suggest that the efficiency drop (in recombination and repair) of interspecies combinations reflects a decrease or the absence of a cooperation between RecA protein and the RecBCD enzyme which normally occurs between these enzymes of the same species. Presumably, this cooperation ensures efficient repair and recombination. It probably relies on species-specific proteinprotein interactions. This is in agreement with the fact that bacterial RecA and RecBCD enzymes, although functionally similar and structurally related, have species-specific primary structures and/or biochemical properties (Akaboshi et al., 1989; Ball et al., 1990; Zhao \& McEntee, 1990; Weichenhan \& Wackernagel, 1989; Rinken et al., 1991).

The indication of a cooperation between the RecA protein and the RecBCD enzyme obtained in this study does not point to the mechanism of cooperation at work. However, on the basis of current models of the RecBCD pathway of recombination (Mahajan, 1988; Smith, 1988; Thaler \& Stahl, 1988) and the biochemical activities of RecA protein and RecBCD enzyme one can envisage cooperative interactions between these enzymes at various steps during the recombination process. Formation of D-loops and the initiation of Holliday junctions are both catalysed by RecA protein (Radding, 1989). The processing of D-loops through cleavage by RecBCD enzyme has been demonstrated (Wiegand et al., 1977; DasGupta et al., 1979). Also the resolution of Holliday junctions is speculated to be catalysed by RecBCD enzyme (Thaler \& Stahl, 1988; Taylor \& Smith, 1990). If so, these reactions could involve an interaction of RecBCD enzyme with RecA protein either bound to single-stranded DNA in the D-loop or still present in the heteroduplex nucleoprotein filament, and this could stimulate recombinant formation (Radding, 1989). Similarly, if the RecBCD enzyme is involved in branch migration, as has been proposed by Kowalczykowski \& Roman (1990), interactions between RecBCD and RecA proteins could facilitate recombination also by adjusting the high rate of DNA unwinding by RecBCD enzyme to the slow RecA-promoted strand transfer (Roman \& Kowalczykowski, 1989a,b). An example of a speciesspecific interaction of recombination proteins has been provided by studies which showed the inability of $\operatorname{Rec}_{P m}$ protein to catalyse strand transfer in the presence of $E$. coli SSB protein and that the ATPase 
activity of $\operatorname{Rec} A_{P_{m}}$ but not of $\operatorname{Rec} A_{E c}$ protein is blocked by $E$. coli SSB protein (West et al., 1983). Further studies aimed at confirming the proposed cooperation of RecA and $\operatorname{RecBCD}$ enzymes by in vitro experiments are necessary.

We thank Dr D. Weichenhan for providing the genomic libraries, Professor Dr R. Eichenlaub for the single-copy cloning vectors, and Dr A. J. Clark and Dr F. Zimoni for bacterial strains. This work was supported by the Deutsche Forschungsgemeinschaft and the Fonds der Chemischen Industrie.

\section{References}

Axaboshi, E., YiP, M. L. R. \& Howard-Flanders, P. (1989). Nucleotide sequence of the recA gene of Proteus mirabilis. Nucleic Acids Research 17, 4390.

BachmanN, B. J. (1972). Pedigrees of some mutant strains of Escherichia coli K-12. Bacteriological Review's 36, 525-557.

BaCHMANN, B. J. (1990). Linkage map of Escherichia coli K-12, edition 8. Microbiological Review's 54, 130-197.

Ball, T. K., Wasmuth, C. R., Braunagel, S. C. \& Benedik, M. J. (1990). Expression of Serratia marcescens extracellular proteins requires recA. Journal of Bacteriology 172, 342-349.

BirNBoIM, H. C. \& Doly, J. (1979). A rapid alkaline extraction procedure for screening recombinant plasmid DNA. Nucleic Acids Research 7, 1513-1523.

Bolivar, F., Rodriguez, R. L., Greene, P. J., Betlach, M. C., Heynecker, H. L., Boyer, H. W., Crosa, J. H. \& Falkow, S. (1977). Construction and characterization of new cloning vehicles. II. A multipurpose cloning system. Gene 2, 95-113.

Clark, A. J. (1973). Recombination deficient mutants of Escherichia coli and other bacteria. Annual Review of Genetics 7, 67-86.

Cox, M. M. \& Lehman, I. R. (1987). Enzymes of general recombination. Annual Review of Biochemistry 56, 229-262.

Csonka, L. N. \& Clark, A. J. (1979). Deletions generated by the transposon $\mathrm{Tn} 10$ in the $s r l$ rec $A$ region of the Escherichia coli $\mathrm{K}-12$ chromosome. Genetics 93, 321-343.

DasGupta, C., Cunningham, R. P., Shibata, T. \& Radding, C. M. (1979). Enzymatic cleavage of D-loops. Cold Spring Harbor Symposia on Quantitative Biology 43, 987-990.

Eitner, G., Solonin, A. S. \& Tanyashin, V. I. (1981). Cloning of a recA-like gene of Proteus mirabilis. Gene 14, 301-308.

HaNaHAN, D. (1983). Studies on transformation of Escherichia coli with plasmids. Journal of Molecular Biology 166, 557-580.

Kowalczykowski, S. C. \& Roman, L. J. (1990). Reconstitution of homologous pairing activity dependent upon the combined activities of purified E. coli RecA, RecBCD, and SSB proteins. In Molecular Mechanisms in DNA Replication and Recombination, pp. 357-373. Edited by C. Richardson \& I. Lehman. New York: Alan R. Liss.

LIAO, C.-L. \& LIU, Y.-T. (1989). Cloning of the Serratia marcescens rec A gene and construction of a Serratia marcescens rec $A$ mutant. Journal of General Microbiology 135, 3319-3327.

LOVETT, S. T. \& CLARK, A. J. (1983). Genetic analysis of regulation of the RecF pathway of recombination in Escherichia coli K-12. Journal of Bacteriology 153, 1471-1478.

MaHAJAN, S. K. (1988). Pathways of homologous recombination in Escherichia coli. In Genetic Recombination, pp. 88-140. Edited by G. R. Smith \& R. Kucherlapati. Washington, DC: American Society for Microbiology.

MaLoY, S. R. \& NUNN, W. D. (1981). Selection for loss of tetracycline resistance by Escherichia coli. Journal of Bacteriology 145, 1110-1112.

Maniatis, T., Fritsch, E. F. \& SAMBroOK, J. (1982). Molecular Cloning, a Laboratory Manual. Cold Spring Harbor, New York: Cold Spring Harbor Laboratory.
McKittrick, N. H. \& SMith, G. R. (1989). Activation of Chi recombinational hotspots by RecBCD-like enzymes from enteric bacteria. Journal of Molecular Biology 210, 485-495.

Miller, J. H. (1972). Experiments in Molecular Genetics. Cold Spring Harbor, New York: Cold Spring Harbor Laboratory.

Murray, N. E., Bruce, S. A. \& Murray, K. (1979). Molecular cloning of the DNA ligase gene from bacteriophage T4. II. Amplification of the gene product. Journal of Molecular Biology 132, 493-505.

Ponticelli, A. S., Schultz, D. W., Taylor, A. F. \& Smith, G. R. (1985). Chi-dependent DNA strand cleavage by RecBC enzyme. Cell 41, 145-151.

RADDING, C. M. (1988). Homologous pairing and strand exchange promoted by Escherichia coli RecA protein. In Genetic Recombination, pp. 193-229. Edited by G. R. Smith \& R. Kucherlapati. Washington, DC: American Society for Microbiology.

RADDING, C. M. (1989). Helical RecA nucleoprotein filaments mediate homologous pairing and strand exchange. Biochimica et Biophysica Acta 1008, 131-145.

Rinken, R., Weichenhan, D., de Vries, J. \& Wackernagel, W. (1991). The RecA-RecBCD dependent recombination pathway of Serratia marcescens and Proteus mirabilis in Escherichia coli: functions of hybrid enzymes and hybrid pathways. Biochimie 73, 375-384.

Roman, L. J. \& KowalCzYKowSKI, S. C. (1989a). Characterization of the helicase activity of the Escherichia coli RecBCD enzyme using a novel helicase assay. Biochemistry 28, 2863-2873.

Roman, L. J. \& KowalczYKowsKi, S. C. (1989 b). Formation of heteroduplex DNA promoted by the combined activities of Escherichia coli RecA and RecBCD proteins. Journal of Biological Chemistry 264, 18340-18348.

Rusche, J. R. \& Howard-Flanders, P. (1985). Hexamine cobalt chloride promotes intermolecular ligation of blunt end DNA fragments by T4 ligase. Nucleic Acids Research 13, 1997-2008.

Sancar, A., Stacheleck, C., Konigsberg, W. \& RupP, W. D. (1980). Sequences of the rec $A$ gene and protein. Proceedings of the National Academy of Sciences of the United States of America 77, 2611-2615.

Schultz, D. W. \& SMITH, G. R. (1986). Conservation of Chi cutting activity in terrestrial and marine enteric bacteria. Journal of Molecular Biology 189, 585-595.

SEdGWICK, S. G. \& Goodwin, P. A. (1985). Differences in mutagenic and recombinational repair in enterobacteria. Proceedings of the National Academy of Sciences of the United States of America 82, 4172-4176.

SMITH, G. R. (1988). Homologous recombination in procaryotes. Microbiological Reviews 52, 1-28.

SMITH, G. R. \& STAHL, F. W. (1985). Homologous recombination promoted by Chi sites and RecBC enzyme of Escherichia coli. BioEssays 2, 244-249.

TAKAGI, T. \& Kisumi, M. (1985). Isolation of a versatile Serratia marcescens mutant as a host and molecular cloning of the aspartase gene. Journal of Bacteriology 161, 1-6.

TAYLOR, A. F. \& SMITH, G. R. (1990). Action of RecBCD enzyme on cruciform DNA. Journal of Molecular Biology 211, 117-134.

Telander-Muskavitch, K. M. \& LinN, S. (1981). RecBC-like enzymes: the exonuclease $V$ deoxyribonucleases. In The Enzymes, vol. 14, pp. 233-250. Edited by P. D. Boyer. New York: Academic Press.

ThaleR, D. S. \& STAHL, F. W. (1988). DNA double-chain breaks in recombination of phage $\lambda$ and of yeast. Annual Review of Genetics 22 , 169-197.

ThOMS, B. \& WACKERNAGeL, W. (1982). UV-induced alleviation of $\lambda$ restriction in Escherichia coli K-12: kinetics of induction and specificity of this SOS function. Molecular and General Genetics 186, 111-117.

Wang, T. V. \& Smith, K. C. (1989). The roles of RecBCD, SSB and RecA proteins in the formation of heteroduplexes from linear-duplex DNA in vitro. Molecular and General Genetics 216, 315-320.

Weichenhan, D. \& WaCkeRnagel, W. (1988). Cloning of the recB, recC, and rec $D$ genes from Proteus mirabilis in Escherichia coli: in vivo formation of active hybrid enzymes. Journal of Bacteriology 170 , 1412-1414.

WEICHENHAN, D. \& WACKERNAGEL, W. (1989). Functional analysis of 
Proteus mirabilis wild-type and mutant RecBCD enzymes in Escherichia coli reveal a new mutant phenotype. Molecular Microbiology 3, 1777-1784.

West, S. C., Countryman, J. K. \& Howard-Flanders, P. (1983). Purification and properties of the RecA protein of Proteus mirabilis. Journal of Biological Chemistry 258, 4648-4654.

Wiegand, R. C., Beattie, K. L., Holloman, W. K. \& Radding, C. M. (1977). Uptake of homologous single-stranded fragments by superhelical DNA. III. The product and its enzymatic conversion to a recombinant molecule. Journal of Molecular Biology 116, 805-824.
Willetts, N. S. \& ClaRK, A. J. (1969). Characteristics of some multiply recombination-deficient strains of Escherichia coli. Journal of Bacteriology 100, 231-239.

YANCEY, S. D. \& PORTER, R. D. (1984). Negative complementation of RecA protein by RecAl polypeptide: in vivo recombination requires a multimeric form of RecA protein. Molecular and General Genetics 193, 53-57.

ZhAO, X.-J. \& MCENTEE, K. (1990). DNA sequence analysis of the recA genes from Proteus vulgaris, Erwinia carotovora, Shigella flexneri and Escherichia coli B/r. Molecular and General Genetics 222, 369-376. 